\title{
VARIETIES OF ENGLISH
}




\title{
Varieties of English
}

An introduction to the study of language

\author{
Dennis Freeborn \\ with \\ Peter French and David Langford
}

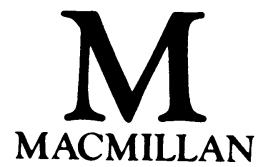


(C) Dennis Freeborn 1986

Softcover reprint of the hardcover 1st edition 1986 978-0-333-37996-7

All rights reserved. No reproduction, copy or transmission of this publication may be made without written permission.

No paragraph of this publication may be reproduced, copied or transmitted save with written permission or in accordance with the provisions of the Copyright Act 1956 (as amended), or under the terms of any licence permitting limited copying issued by the Copyright Licensing Agency, 33-4 Alfred Place, London WC1E 7DP.

Any person who does any unauthorised act in relation to this publication may be liable to criminal prosecution and civil claims for damages.

First published 1986

Reprinted 1986 (with corrections), 1987, 1988, 1989

Published by

MACMILLAN EDUCATION LTD

Houndmills, Basingstoke, Hampshire RG21 2XS

and London

Companies and representatives

throughout the world

British Library Cataloguing in Publication Data

Freeborn, Dennis

Varieties of English.-(Studies in English

language)

1. English language-Grammar-1950-

I. Title II. Langford, David III. French,

Peter IV. Series

428 PE1112

ISBN 978-0-333-37997-4

ISBN 978-1-349-18134-6 (eBook)

DOI 10.1007/978-1-349-18134-6

In case of difficulty in obtaining the cassette, please send your order to: Globe Education, FREEPOST, Brunel Road, Basingstoke, Hampshire, RG21 2BR. Please quote the title, author and ISBN on all orders. 


\section{Contents}

Contents of the cassette tape viii

Symbols ix

Acknowledgements $\quad$ x

Introduction $\quad$ xi

1 Variety, change, and the idea of correct English 1

1.1 Good English 1

1.2 A Letter to the Editor 2

1.3 An Acceptability Test 9

1.3.1 Attitudes to English usage in the past 9

1.3.2 Attitudes to English usage today 11 Acceptability test 11

1.4 This is the six o'clock news - belt up! 17

1.5 Is there a language trap? 20

2 Dialects and Standard English - the past 22

2.1 How the English language was brought to Britain 22

2.2 Britain before the English came 24

2.3 The Vikings 26

2.4 The Norman Conquest 28

2.5 The establishment of Standard English 30

2.6 How to analyse a historical text 32

2.6.1 Old English 32

2.6.2 Middle English 33

2.6.3 Early Modern English and Modern
English

3 Dialects and Standard English - the present 41

3.1 Standard English a dialect 41

3.2 Present-day dialectal forms 42 
3.3 Creole English 56

The mango tree 57

The red bird 60

3.4 Pidgin English

4 Regional accents and Received Pronunciation 64

4.1 The difference between accent and dialect 64

4.2 Accent 67

4.3 Boundaries of regional variation $\quad 69$

4.4 A framework for accent study $\quad 74$

4.4.1 How to make a phonetic transcription $\quad 75$

4.5 Practical exercises in phonetic transcription 77

4.6 A practical exercise in transcribing a regional accent $\quad 78$

4.7 Social evaluation of accents $\quad 81$

4.8 Accents and social variables $\quad 84$

5 Spoken English and Written English 86

5.1 Speech and writing as media for language $\quad 86$

5.2 Making a transcription $\quad 87$

5.3 Dialogue 1: Making a model village 88

5.3.1 Transcription of the dialogue 89

5.3.2 Romy's writing 91

5.4 Dialogue 2: At the riding school 96

5.4.1 Rebecca's writing 96

5.4.2 Transcription of part of the dialogue 98

6 Learning to talk 102

6.1 Language learning a complex skill 102

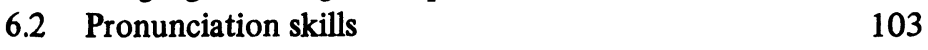

6.3 Grammatical skills 109

$\begin{array}{lll}\text { 6.3.1 Kirsty } & 110\end{array}$

6.3.2 Danny 111

6.4 Discourse and conversation skills $\quad 1.18$

$\begin{array}{lll}6.4 .1 & \text { Turn-taking } & 119\end{array}$

6.4.2 Coherence, or fitting-in 121

6.4.3 Response to other speakers' needs 124 
7 Variety and style in spoken English 126

$\begin{array}{lll}7.1 & \text { Bedtime stories } & 127\end{array}$

7.1.1 Susan's narrative 127

7.2 Unscripted commentary 135

7.2.1 Goal! 135

7.2.2 Trooping the Colour 143

7.2.3 Snooker match 144

$\begin{array}{lll}7.3 & \text { Conversation } & 145\end{array}$

8 Variety and style in written English - I.

Reporting the news $\quad 152$

$\begin{array}{ll}\text { 8.1 What the headlines say } & 152\end{array}$

Events at British Leyland 157

$\begin{array}{ll}8.2 \text { News reporting } & 162\end{array}$

$\begin{array}{lll}8.2 .1 & \text { Style } & 162\end{array}$

8.2.2 Ideology and bias 165

(1) Sheffield incident 168

(2) Belfast incident $\quad 170$

9 Variety and style in written English - II.

The language of literature $\quad 182$

9.1 The Preacher 182

9.2 The Good Samaritan again 185

9.3 Exercises in Style - from the French 186

9.4 Some notes on verse 195

9.4.1 Rhythm and stress in speech 195

9.4.2 Metre 196

9.4.3 The line in verse 200

9.4.4 Grammatical deviance in verse 203

9.4.5 Patterns of rhythm and sound in verse 205

9.5 Dialect in literature 207

$\begin{array}{ll}\text { Booklist } & 212\end{array}$

Index 217 


\section{Contents of the cassette tape}

Chapter 1 p. 18 Tom Leonard

p. 19 Wilfred Pickles reading the news

Chapter 3 p. 55 Dialect sentences

p. 57 The mango tree

p. 60 The red bird

Chapter 4 p. 65 Mrs Cook

p. 69 Mr Archer

p. 75 The sounds of English

p. 78 RP (i)

p. 78 RP (ii)

p. 78 Ashington, Northumberland

p. 81 London Cockney (i)

p. 81 London Cockney (ii)

Chapter 5 p. 89 Romy

p. 98 Rebecca

Chapter 6 p. 103 Pronunciation skills, Danny, Stages A, B, C

p. 112 Grammatical skills, Danny, Stages A, B, C

p. 121 Discourse skills, Mother and Stephanie

Chapter 7 p. 127 Bedtime stories (i)

p. 134 Bedtime stories (ii)

p. 136 Unscripted commentary (i) Goal!

p. 143 Unscripted commentary (ii) Trooping the Colour

p. 145 Conversation

p. 147 (i) Tom B. and Mrs W.

p. 148 (ii) Heather and Mrs W.

p. 149 (iii) Tom, Marion, and the Minister 


\section{Symbols}

Words or phrases quoted as linguistic examples are printed in italics.

A symbol in pointed brackets, e.g. 〈d〉, refers to its use as a letter in written English.

A symbol or word in slanting brackets, e.g. /u:/, /peg/, refers to sounds or pronunciation in spoken English, and uses the symbols of the International Phonetic Alphabet (see chapter 4).

In transcribing conversation, pauses are shown in round brackets, either in terms of their approximate length in seconds, e.g. (2.0), or as a momentary break, or micropause (.). When an overlap of speaking turns. occurs, the place where the overlap begins is shown as $/ /$.

The symbol $\emptyset$ indicates a deleted element.

Note to teachers and lecturers: this book does not make use of the concept of the phoneme in discussing spoken English, although it is a fundamental part of the study of phonology in linguistics. Many students do not find the theory of the phoneme easy to grasp at first, and in the brief introductory survey of aspects of spoken English in chapters 4, 5, and 6, it was thought better to establish an uncomplicated approach to pronunciation, even though it avoids some basic problems.

This should not deter teachers from introducing the concept and using the term phoneme if they wish, especially if they are teaching the phonology of English as part of a wider syllabus in the study of the language. 


\section{Acknowledgements}

The author and publishers wish to thank the following who have kindly given permission for the use of copyright material:

Sir John Colville for his letter to The Times.

Faber and Faber Limited for extract from 'The Waste Land' by T.S. Eliot in Collected Poems 1909-1962 by T. S. Eliot; and extract from 'Cut Grass' by Philip Larkin in High Windows by Philip Larkin. Mr Tom Leonard for his poem about the 6 o' clock News. Oxford University Press for extracts from 'God's Grandeur' and 'The Wreck of the Deutschland' in Selected Poems, edited by Gardner. Penguin Books Ltd for extract from Bede: $\boldsymbol{A}$ History of the English Church and People, trans. Leo Sherley-Price (Penguin Classics, Revised edition 1968). Copyright ( ) Leo Sherley-Price 1955, 1968.

The Society of Authors as the literary representative of the Estate of A. E. Housman, and Jonathan Cape Ltd., publishers of A. E. Housman's Collected Poems for adaptation of 'On Wenlock Edge' by A. E. Housman text from OBEV.

Every effort has been made to trace all the copyright holders but if any have been inadvertently overlooked the publishers will be pleased to make the necessary arrangement at the first opportunity. 


\section{Introduction}

The purpose of this book is to demonstrate how the formal study of language - linguistics - can be applied to written and spoken English in order to describe styles and varieties of language use precisely and accurately. The approach is empirical, that is, 'based or acting upon observation or experiment'.

Each text provides a distinctive sample of English in use. The descriptive commentaries show how a linguistic study can help to identify those features of a text which make it distinctive. The studies are not primarily concerned with evaluating the texts, to say whether they are good or bad of their kind, but will form a sound basis for critical discrimination where this is appropriate.

Chapter 1 looks at people's beliefs about, and attitudes to, good or correct English. Chapters 2, 3 and 4 discuss how English has changed in time over 1,000 years and more, and how it now varies according to geographical region and social class. Chapter 5 examines the differences between spoken and written English - that is, variations in the medium which we use to communicate with other people in the English language. Chapter 6 gives examples of the successive varieties of children's speech before they use, more or less, the English of their parents and other adults.

Finally, chapters 7,8 and 9 present some familiar varieties of spoken and written English which are associated with specific functions, 'the language of ...', styles of speech or writing which change to suit the occasion, the people addressed, and the topic under discussion. Studying the examples of style in English should help you to be much more aware of how you adopt an appropriate one.

In order to demonstrate this methodical approach to the description of style in sufficient detail, the number of topics has had to be restricted. There are many more varieties of English than those discussed in this book, but a similar process of analysis and description to that demonstrated here can be used on any other variety. 


\section{How to use the book}

The chapters are subdivided into topics, and give exercises which should be discussed and worked before going on to examine the descriptive commentaries which follow. The commentaries are sometimes detailed, and are intended to teach important basic concepts about the language.

Some topics include further texts and exercises without commentary, but in the restricted space of a single textbook it is not possible to include many texts for additional study. Teachers and lecturers will be able to provide their own follow-up work.

It is not essential to follow the order of the chapters consecutively. Some teachers may prefer to select or to begin, for example, with chapter 5 on spoken and written English, rather than with chapter 1 on attitudes to good English.

The linguistic features which are described arise in an ad hoc way from the nature and style of each individual text. The book does not, therefore, cover all aspects of the sound and sentence patterns of English, since some may not appear in the selected texts. Others, on the other hand, occur more than once. When the linguistic features are identified, they are related to the meaning and function of the texts. It is hoped that teachers and lecturers will find the texts useful for other topics in English teaching which are either not mentioned in the commentaries, or only referred to in passing.

Teachers must decide for themselves how to relate this study of varieties of English to the necessary understanding of the phonology and grammar of the language which makes it possible. Theory and practice may be taught concurrently, with the teacher using the texts to demonstrate in greater detail those aspects of the sound or sentence structure that arise from them. Alternatively, the texts may be studied after an introduction to the phonology and grammar of English has begun.

In chapters 4 and 6 especially, students will need help from their teachers in learning to transcribe the sounds of speech and to distinguish the features of dialectal accent and children's language. The exercises provided are minimal, and limitations of space make it impossible to provide a more detailed, step-by-step approach to transcription. Chapter 4 is not in itself a complete introduction to the sound patterns of English, and presupposes additional teaching.

It is certain that only a limited understanding will be possible if the texts are studied without some model of language and its appropriate 
terminology being available to the student. The terminology used in this book is largely traditional and well established. Only those terms which are necessary for a satisfactory analysis or description are introduced. The accompanying cassette tape is essential for a proper study of the transcription of spoken English. 